\title{
Effects of Leptin, Resistin, and PPAR-Gama Gene Variants on Obese Patients with Acute Coronary Syndrome in the Turkish Population
}

\author{
(1) Akif Arat1, (1) Ümit Yılmaz1, (1) Nesibe Yılmaz1, (1) Osman Fazlıŏulları2, (1) Faruk Çelik1, (1) Cem Başaran3, \\ (1) Ümit Zeybek1 \\ ${ }^{1}$ İstanbul University, Aziz Sancar Institute of Experimental Medicine, Department of Molecular Medicine, İstanbul, Turkey \\ ${ }^{2}$ Avicenna Hospital, Clinic of Cardiovascular Surgery, İstanbul, Turkey \\ ${ }^{3}$ Medicana Bahçelievler Hospital, Clinic of Cardiovascular Surgery, İstanbul, Turkey
}

Cite this article as: Arat A, Yılmaz Ü, Yılmaz N, Fazlıoğulları O, Çelik F, Başaran C, Zeybek Ü. Effects of Leptin, Resistin, and PPAR-Gama Gene Variants on Obese Patients with Acute Coronary Syndrome in the Turkish Population. J Acad Res Med 2020;10(2):166-74

\begin{abstract}
Objective: Obesity and acute coronary syndrome (ACS) are common health problems of recent years. There are many candidate genes related to the genetic infrastructure of ACS and obesity. This study aimed to investigate the association of Leptin glutamine to arginine substitution (Gln223Arg), Resistin-420 Cytosine/Guanine (C/G), and proliferator-activated receptor-gamma (PPAR- $\gamma$ ) proline to alanine substitution (Pro12Ala) polymorphisms in obese patients with ACS in the Turkish population.

Methods: Fifty obese patients concurrently diagnosed with ACS and 42 healthy controls were included in this study. These polymorphisms were analyzed using the polymerase chain reaction-restriction fragment length polymorphism and agarose gel electrophoresis methods.

Results: The PPAR- $\gamma$ Pro12Ala polymorphism Pro/Ala genotype $(p=0.001)$ was found to be higher in the obese patients with ACS, while the (Proline/ Proline) genotype ( $p=0.001)$ was significantly higher in the control group. The GC genotype $(p=0.045)$ distribution of Resistin- $420 \mathrm{C} / \mathrm{G}$ was found to be significantly higher in the controls compared to the patient group.

Conclusion: Our study presents new findings that the PPAR- $\gamma$ Pro12Ala polymorphism Pro/Ala genotype is a risk factor for ACS in obese individuals, whereas Resistin-420 C/G polymorphism GC genotype and PPAR- $\gamma$ Pro12Ala polymorphism Pro/Pro genotype may be protective factors for ACS in obese individuals.
\end{abstract}

Keywords: Acute coronary syndrome, leptin, resistin, PPAR- $\gamma$, gene polymorphism, PCR-RFLP 


\section{INTRODUCTION}

Acute coronary syndrome (ACS) is the most common reason for emergency department visits and hospital admissions. ACS is one of the most important health problems causing morbidity, mortality, and reduced quality of life in today's society (1). Obesity is a multifactorial disease characterized by an excessive increase in the amount of body fat, adversely affecting health and the quality of life, reducing the lifespan, and causing many metabolic diseases (2). According to the World Health Organization's reports, obesity affects more than 700 million people worldwide and nearly 2.3 billion people are overweight (3). Obese individuals have a higher frequency of cardiovascular risk factors and have higher morbidity and mortality rates related to cardiovascular diseases (4). Previously, many studies showed that some gene polymorphisms are associated with obesity and cardiovascular diseases $(5,6)$. Leptin, which is one of these genes, is expressed in adipocytes and regulates adiposetissue mass, food intake, energy expenditure, and body weight (7). Many studies have demonstrated that the leptin gene or leptin receptor gene polymorphisms regulate obesity and cardiovascular pathogenesis $(8,9)$. Resistin is a novel hormone that is secreted by adipocytes and its gene is located on chromosome 19p13.2 (10). Resistin-420 Cytosine/Guanine (C/G) polymorphism, located in the promoter region of the resistin gene, was reported to be associated with the regulation of resistin gene expression and serum resistin level (11). In addition, an association has been shown between the Resistin-420 C/G variant and diabetes, obesity, and cardiovascular disease in several studies (12-14). The peroxisome proliferator-activated receptor-gamma (PPAR- $\gamma$ ), localized on chromosome 3p25, is another related gene that is mainly expressed in adipose tissue, the colon, and macrophages. PPAR- $\gamma$ plays a role in adipocyte differentiation and in the regulation of insulin responses, and it is linked to numerous diseases such as obesity, diabetes, atherosclerosis, and cancer (15).

It is suggested that Leptin Glutamine to Arginine substitution (GIn223Arg), Resistin-420 C/G, and PPAR- $\gamma$ proline to alanine substitution (Pro12Ala) gene polymorphisms play an important role in the development of diabetes, obesity, and cardiovascular disease. However, there is no previous study that has investigated the combined effect of the variations of Leptin, Resistin, and PPAR- $\gamma$ genes on the pathogenesis of ACS among obese patients in the Turkish population. Therefore, this study is the first to investigate the possible associations of Leptin Gln223Arg, Resistin-420 C/G, and PPAR- $\gamma$ Pro12Ala gene polymorphisms together in obese patients with ACS.

\section{METHODS}

\section{Ethical Approval}

This research complies with all the relevant national regulations, institutional policies and is in accordance the tenets of the Helsinki Declaration, and has been approved by the İstanbul Faculty of Medicine Ethical Committee, İstanbul University (approval number: 2012/1590-1251). All the participants' rights were protected and written informed consents were obtained before the procedures according to the Helsinki Declaration.

\section{Study Group}

The Leptin Gln223Arg, Resistin-420 C/G, and PPAR- $\gamma$ Pro12Ala gene polymorphisms were investigated in 42 healthy subjects without any heart disease and 50 patients diagnosed with obesity and ACS. The patients were selected from the Medicana Bahçelievler Hospital, Clinic of Cardiovascular Surgery in İstanbul, Turkey.

The patient group consisted of obese patients [body mass index (BMI) $\square 30$ ] who were diagnosed with ACS in the hospital and whose samples were collected. ST segment elevated q positive or non-ST segment elevated, but enzyme positive patients were included into this group. Unstable angina pectoris patients were excluded. The control group consisted of people who were working in the same hospital, recruited via a survey. Particularly, the lack of a family history was the main criteria for maintaining the survey. While creating the control group, the age range was matched with that of the patient group.

\section{DNA Isolation and Genotyping}

In EDTA containing tubes, $10 \mathrm{~mL}$ of venous blood samples were obtained from the participants. Samples were stored at $-20^{\circ} \mathrm{C}$ until the genomic DNA isolation was performed using the salting out method (16). The PPAR- $\gamma$ Pro12Ala, Resistin-420 C/G, and Leptin Gln223Arg polymorphisms were analyzed using the polymerase chain reaction (PCR)-restriction fragment length polymorphism methods. For detection of PPAR- $\gamma$ Pro12Ala, Resistin-420 C/G, and Leptin Gln223Arg, 500 ng genomic DNA was amplified with 10x reaction buffer $(10 \mathrm{mM}$ Tris- $\mathrm{HCl}, 50 \mathrm{mM}$ of $\mathrm{KCl}, 1.75 \mathrm{mM}$ $\mathrm{MgCl}$ ), $2.5 \mathrm{mM}$ of each dNTP, $100 \mathrm{pmol} / \mu \mathrm{L}$ of each primer, and 0.1 unit Taq polymerase (Invitrogen) in a $25 \mu \mathrm{L}$ reaction volume. The annealing temperatures for Leptin Gln223Arg, Resistin-420 $\mathrm{C} / \mathrm{G}$, and PPAR- $\gamma$ Pro12Ala polymorphisms were $64^{\circ} \mathrm{C}, 63^{\circ} \mathrm{C}$, and $58^{\circ} \mathrm{C}$, respectively.

Used primers, restriction enzymes, and interpretations for determining Leptin Gln223Arg, Resistin-420 C/G, and PPAR- $\gamma$ Pro12Ala polymorphisms are shown in Table 1.

\section{Evaluation of the Mspl, Bpil, and BstUI Restriction Enzyme Digestion Results}

The PCR yield of the Leptin GIn223Arg polymorphism was 421 $\mathrm{bp}$ and the bands obtained following digestion with Mspl were 294 and 127 bp, only if the polymorphism was present. Therefore, a single band of $421 \mathrm{bp}$ was appraised as Thymin/Thymin (TT) (wild type, TT), 294 and 127 bp as Cytosine/Cytosine (CC) (mutant type, CC), and 421, 294, and $127 \mathrm{bp}$ as Cytosine/Thymine (CT) (heterozygous type, CT) (Figure 1).

In order to evaluate the Resistin-420 C/G polymorphism, Bpil restriction enzyme was utilized. A single band of 533 was 
appraised as Guanine/Guanine (GG) (329 and 204 bp as CC (mutant type, CC), and 533, 329 and 204 bp as Guanine/Cytosine (GC) (heterozygous type, GC) (Figure 2).

The PCR yield of the PPAR- $\gamma$ Pro12Ala polymorphism was $270 \mathrm{bp}$ and the bands obtained following digestion with BstUI were 227 and $43 \mathrm{bp}$, only if the polymorphism was present. Therefore, a single band of $270 \mathrm{bp}$ was appraised as Proline/Proline (Pro/Pro) (wild type, Pro/Pro), 227 and $43 \mathrm{bp}$ as Ala/Ala (mutant type, Ala/ Ala: Alanine/Alanine), and 270, 227, and $43 \mathrm{bp}$ as Proline/Alanine (Pro/Ala) (heterozygous type, Pro/Ala) (Figure 3).

\section{Statistical Analysis}

Statistical analysis was performed using SPSS version 11.5 (SPSS Inc, Chicago, USA). The chi-square $\left(\chi^{2}\right)$ test, Fischer's exact test, and Student's t-test were used for comparison of the numerical variables between the groups. Allele frequencies were calculated by the gene counting method. Chi-square $\left(\chi^{2}\right)$ test was used for the comparison of clinical and non-clinical parameters and alleles. Student's t-test and ANOVA test were performed to compare the genotypes with more than two variables. Values of $p<0.05$ were considered as statistically significant.

\section{RESULTS}

Fifty obese patients with ACS and 42 healthy controls were included in the analyses. The mean ages of the patient and control groups were $61.56 \pm 8.92$ and $60.34 \pm 12.55$ years, respectively. No significant difference was found between the patients and the

Table 1. Polymerase Chain Reaction-Restriction Fragment Length Polymorphism-Based Assay of Leptin GLN223ARG, Resistin-420 C/G, and PPAR- $y$ PRO12ALA SNPs

\begin{tabular}{|c|c|c|c|}
\hline SNPs & Primers & Restriction enzymes & Interpretation (bp) \\
\hline PPAR- $\gamma$ PRO $12 A L A$ & $\begin{array}{l}\text { Forward Primer: } \\
\text { 5'-GCCAATTCAAGCCCAGTC-3' } \\
\text { Reverse Primer: } \\
\text { 5'-GATATGTTTGCAGCAAGTG } \\
\text { AATCATAAGGAATCGCTTTCCG-3' }\end{array}$ & BstUI & $\begin{array}{l}\text { PP: } 270 \\
\text { AA: } 227+43 \\
\text { PA: } 270+227+43\end{array}$ \\
\hline Resistin - 420 C/G & $\begin{array}{l}\text { Forward Primer: } \\
\text { 5'- TGTCATTCTCACCCACAG } \\
\text { ACA-3' } \\
\text { Reverse primer: } \\
\text { 5'- TGGGCTCAGCTAACCAA } \\
\text { ATC-3' }\end{array}$ & Bpil & $\begin{array}{l}\text { GG: } 533 \\
\text { CC: } 329+204 \\
\text { GC: } 533+329+204\end{array}$ \\
\hline Leptin GLN223ARG & $\begin{array}{l}\text { Forward Primer: } \\
\text { 5'-ACCCTTTAAGCTGGGTGT } \\
\text { CCCAAATAG-3' } \\
\text { Reverse Primer: } \\
\text { 5'- CTAGCAAATATTTTTGTAA } \\
\text { GCAATT-3' }\end{array}$ & Mspl & $\begin{array}{l}\text { TT: } 421 \\
\text { CC: } 294+127 \\
\text { CT: } 421+294+127\end{array}$ \\
\hline
\end{tabular}

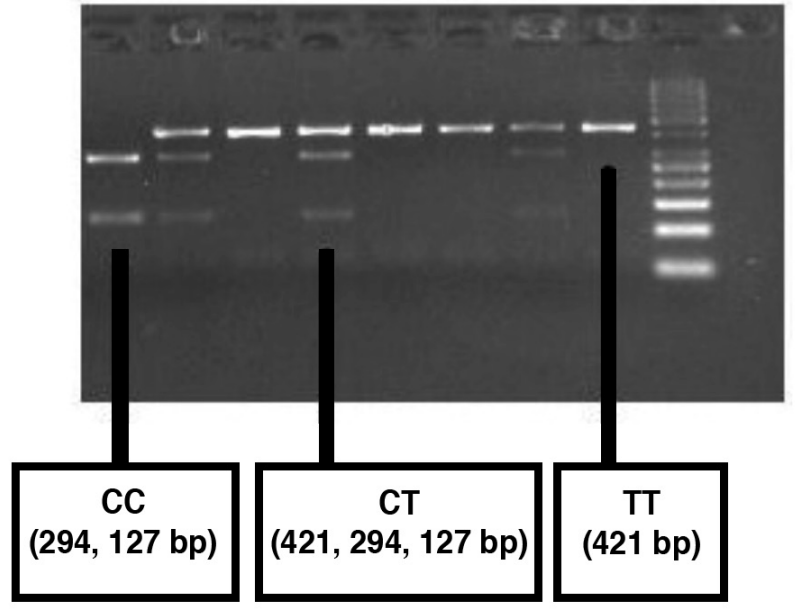

Figure 1. Gel photograph showing PCR-RFLP assay for genotyping of Leptin Gln223Arg polymorphism PCR-RFLP: Polymerase chain reaction restriction-fragment length polymorphism, CC: cytosine-cytosine, CT: cytosine/thymine, TT: thymin/ thymin

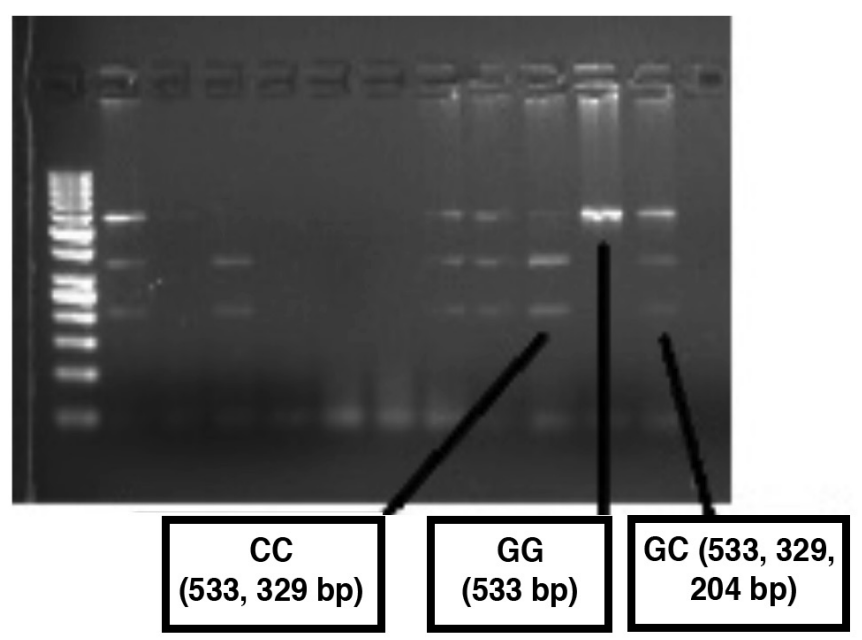

Figure 2. Gel photograph showing PCR-RFLP assay for genotyping of Resistin-420 C/G polymorphism

PCR-RFLP: Polymerase chain reaction restriction-fragment length polymorphism, CC: cytosine-cytosine, GG: guanine/guanine, GC: Guanine/Cytosine 
controls in terms of age. Demographic parameters of the study groups are shown in Table 2. BMI $[p=0.001,95 \%$ confidence interval (Cl): 5.63-8.25], very-low-density lipoprotein-cholesterol

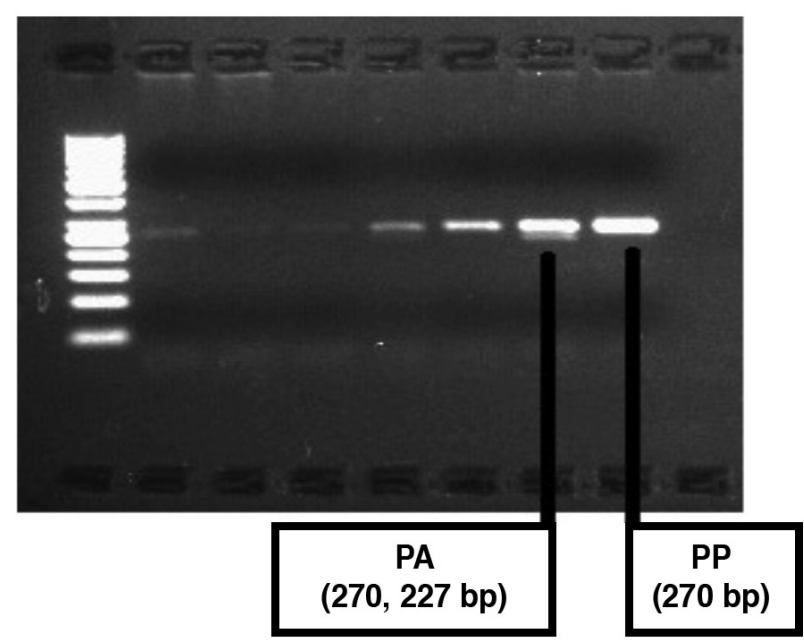

Figure 3. Gel photograph showing PCR-RFLP assay for genotyping of PPAR- $\gamma$ Pro12Ala polymorphism

PCR-RFLP: Polymerase chain reaction restriction-fragment length polymorphism $(p=0.001,95 \% \mathrm{Cl}: 9.94-30.00)$, and triglyceride $(p=0.001,95 \% \mathrm{Cl}$ : 49.87-150.29) levels were found to be significantly higher in the patient group compared to the controls. Also, LDL-cholesterol $(p=0.002,95 \% \mathrm{Cl}: 10.77-44.15)$ and high-density lipoproteinscholesterol ( $p=0.001,95 \% \mathrm{Cl}: 8.65-18.28$ ) levels were found to be higher in the controls than in the patient group. In addition, $66 \%$ of individuals in the patient group were also diagnosed with hypertension and $36 \%$ with diabetes mellitus (DM).

When we evaluated the study groups in terms of the PPAR- $\gamma$ Pro12Ala genotype and allele frequencies, none of the individuals in either group showed the Ala/Ala genotype. In the patient group, Pro/Ala genotype was found to be significantly higher compared to the controls ( $p=0.001,95 \% \mathrm{Cl}$ : 3.82-17.22). Due to the absence of the Ala/Ala genotype, carrying the mutant Ala/Ala allele presents as the Pro/Ala genotype. The Pro/Pro genotype frequency was determined to be significantly higher in the control group compared to the patient group ( $p=0.001,95 \% \mathrm{Cl}$ : $0.004-$ 0.202) (Table 3). The allele and genotype frequencies of Leptin Gln223Arg polymorphism were not significantly different between the patient group and controls (Table 3). According to the results of the statistical analysis of Resistin-420 C/G polymorphism, the GC genotype distribution was determined to be significantly

\section{Table 2. Demographic characteristics of obesity with ACS patients and healthy controls}

\begin{tabular}{|l|l|}
\hline Demographic parameters & Patient $(\mathbf{n}=50)$ \\
\hline Age (year) & $(61.56 \pm 8.92)$ \\
\hline Gender (F/M) & $17 / 33$ \\
\hline Body mass index $\left(\mathrm{kg} / \mathrm{m}^{2}\right)$ & $(32.75 \pm 2.76)^{\mathrm{a}}$ \\
\hline Presence of hypertension (\%) & $66 \%$ \\
\hline Presence of diabetes mellitus (\%) & $36 \%$ \\
\hline Presence of KOAH (\%) & $8 \%$ \\
\hline LDL-cholesterol (mg/dL) & $(103.84 \pm 43.05)$ \\
\hline Triglyceride (mg/dL) & $(216.18 \pm 168.22)$ \\
\hline Total cholesterol (mg/dL) & $(185.41 \pm 61.83)$ \\
\hline HDL-cholesterol (mg/dL) & $(38.34 \pm 9.75)$ \\
\hline VLDL-cholesterol (mg/dL) & $(43.23 \pm 33.64)$ \\
\hline AST (mg/dL) & $(30.54 \pm 14.03)$ \\
\hline ALT (mg/dL) & $(36.89 \pm 20.41)$ \\
\hline BUN (mg/dL) & $(19.50 \pm 9.02)$ \\
\hline Hematocrit & $(40.49 \pm 5.18)$ \\
\hline Platelet & $(266.18 \pm 52.29)$ \\
\hline Urea & $(38.55 \pm 13.06)$ \\
\hline WBC & $(7.63 \pm 2.17)$ \\
\hline INR & $(1.06 \pm 0.14)$ \\
\hline Sedimentation & $(35.36 \pm 25.82)$ \\
\hline
\end{tabular}

Values are reported as number of patients, n: number of individuals, SD: standard deviation, ap $<0.05$ denoted statistically significant, F: female, M: male, ACS: acute coronary syndrome, KOAH: Chronic Obstructive Pulmonary disease, HDL: high-density lipoproteins, VLDL: very-low-density lipoprotein, AST: aspartate aminotransferase, ALT: alanine aminotransferase, BUN: blood urea nitrogen, WBC: white blood cell, INR: international normalized ratio 
higher in the controls compared to the patient group $\left[p=0.045, \chi^{2}\right.$ : 4.033, odds ratio (OR): 1.364, 95\% Cl: 1.003-1.854] (Table 3).

When we investigated the association between demographic parameters and Leptin Gln223Arg, Resistin-420 C/G, and PPAR- $\gamma$ Pro12Ala genotype distribution, the Leptin GG genotype carriers had significantly higher BMls compared to heterozygote carriers in the patient group.

There were no significant differences between other polymorphisms and demographic parameters in both study groups (Table 3).

\section{DISCUSSION}

Leptin receptor Gln223Arg polymorphism is one of the most frequently encountered leptin receptor polymorphisms (17). Leptin GIn223Arg polymorphism falls within the region encoding the extracellular domain of the leptin receptor. Therefore, the amino-acid changes consecutively, leading to a change from a neutral to a positive charge of the molecule, in the extracellular domain of the receptor that represents a typical leptin-binding site and it was suggested that a change of charge could significantly affect the functionality of the receptor $(18,19)$. Leptin Gln223Arg polymorphism affected the development process of coronary artery disease via facilitating the deposition of HDL cholesterol on blood vessel walls (20). While some studies have reported that Leptin Gln223Arg polymorphism has been associated with BMI, high blood pressure, obesity, lipids, and insulin resistance, other studies did not find any association with these parameters (21).

Although Leptin receptor Gln223Arg polymorphism has not been associated with lipid parameters in obese or normal- weight persons before $(22,23)$, some studies showed that it may increase the risk of obesity and/or obesity-related diseases in different populations (24-26). In obese children, no association was found between Leptin Gln223Arg polymorphism and obesity, leptin, insulin resistance, and metabolic abnormalities (27). Similarly, Okada et al. (28) have found no association between Leptin GIn223Arg polymorphism and serum lipid profiles of Japanese obese children. Leptin Gln223Arg polymorphism was found not to be associated with obesity in Turkish children with metabolic syndrome (29). There was no difference in the genotype frequencies of Leptin Gln223Arg polymorphism between obese and non-obese adolescents (18). Yang et al. (30) selected fifteen studies for their meta-analysis. They reported a significant association between decreased risk of obesity and the Leptin Gln223Arg polymorphism. Overweight or obese subjects had significantly higher frequencies of the Arg223 homozygous allele of the Leptin Gln223Arg polymorphism (31). In a study conducted in the Iranian population, it has been suggested that carrying the $G$ allele increases the risk of non-ST-segment elevation myocardial infarction (32). In another study, Leptin GIn223Arg polymorphism has not been associated with the risk of coronary artery disease and hypertension in the Iranian population (33). Aijälä et al. (34) have reported that no impact on incidence for cardiovascular events or death was detected between Leptin GIn223Arg polymorphism. Also, Shi et al. (20) have demonstrated that Leptin Gln223Arg polymorphism showed a significant difference between coronary artery disease patients and healthy controls neither genotypes nor alleles in China population. In the represented study, we found no association between the Leptin Gln223Arg polymorphism and obese patients with ACS in the Turkish population. A meta-

\begin{tabular}{|c|c|c|c|c|}
\hline SNPs & Genotype and alleles & Patient $(n=50)(n, \%)$ & Control (n 42) (n, \%) & $\mathrm{p}$ \\
\hline \multirow{5}{*}{ Leptin GLN223ARG } & AA & $14(28)$ & $18(42.90)$ & - \\
\hline & GG & $2(4)$ & $3(7.10)$ & - \\
\hline & $A G$ & $34(68)$ & $21(50)$ & - \\
\hline & A allele & $62(62)$ & $57(67.85)$ & - \\
\hline & G allele & $38(38)$ & 27 (32.15) & - \\
\hline \multirow{5}{*}{ PPAR- $\gamma$ PRO12ALA } & PP & $6(12)$ & $38(97.40)^{a}$ & 0.001 \\
\hline & AA & 0 & 0 & - \\
\hline & PA & $44(88)^{a}$ & $1(2.60)$ & 0.001 \\
\hline & P allele & $56(56)$ & 77 (98.71) & - \\
\hline & A allele & $44(44)$ & $1(1.29)$ & - \\
\hline \multirow{5}{*}{ Resistin-420 C/G } & GG & $9(20.5)$ & $5(12.5)$ & - \\
\hline & $\mathrm{CC}$ & $10(22.7)$ & $4(10)$ & - \\
\hline & GC & $25(56.8)$ & $31(77.5)^{a}$ & 0.045 \\
\hline & G & $43(48.86)$ & $41(51.25)$ & - \\
\hline & C & $45(51.14)$ & $39(48.75)$ & - \\
\hline
\end{tabular}

Values are reported as number of patients (percentage of total group). ${ }^{2} \mathrm{p}<0.05$ denoted statistically significant. PPAR- $\gamma$ : peroxisome proliferator-activated receptorgamma, GG: guanine/guanine, CC: cytosine-cytosine, GC: Guanine/Cytosine 
analysis showed that Leptin Gln223Arg polymorphism was not significantly associated with cardiovascular disease risk, but have claimed that these findings are still unclear, because the frequency of the 223Arg allele was highly varied in different ethnicities (8).

The resistin gene coding resistin is found on chromosome 19p13; Resistin-420C/G polymorphism reported at promoter as well as on coding sequences. One of the most frequently studied polymorphisms, $C$ to $G$ substitution at -420 position in the $5^{\prime}$ flanking region of the gene showed altered resistin gene expression (mRNA levels) in abdominal fat with increased serum resistin level (35). This polymorphism has independently been associated with cardiovascular risk factors, such as insulin resistance, type 2 diabetes mellitus (T2DM), obesity, hypertension, dyslipidemia, and metabolic syndrome, as well as with coronary heart disease (arteriosclerosis, coronary artery disease, idiopathic dilated cardiomyopathy) (36-39). In a meta-analysis, G allele of Resistin-420 C/G polymorphism was reported as a risk factor for obesity (40). The Resistin-420 GG genotype was significantly associated with obesity, impaired glucose tolerance, and T2DM in a Egyptian population (41). G/G genotypes and $G$ alleles for Resistin-420 C/G polymorphism were significantly associated with T2DM and cardiovascular disease in Egyptian diabetic patients (12). Also, Nakashima et al. (42) have reported that carrying the GG genotype and $\mathrm{G}$ allele increased cardiovascular disease risk. In a Chinese population, subjects with CG and GG genotypes had an increased risk of coronary artery disease compared to CC carriers (11). Hoffman et al. (43) did not find any association between Resistin-420 C/G polymorphism and coronary artery disease in Caucasians. Hussain et al. (44) reported that elevated serum resistin levels and carrying the $\mathrm{G}$ allele for Resistin- $420 \mathrm{C} / \mathrm{G}$ polymorphism may be associated with hypertrophic cardiomyopathy. In the Chinese population, no significant difference in the distribution of genotypes and allele frequencies of $-420 \mathrm{C} / \mathrm{G}$ polymorphism has been found in T2DM patients and coronary heart disease patients (45). Resistin-420 C/G polymorphism has been found associated with increased obesity and metabolic syndrome, but it is not different in subjects with high cardiovascular diseases such as myocardial infarction (46). Resistin-420 C/G polymorphism was not associated with metabolic syndrome or coronary atherosclerosis in nondiabetic Caucasians (47). According to our results, the GC genotype distribution for Resistin-420 C/G polymorphism was determined to be significantly higher in the control group compared to obese patients with ACS; therefore, it can be said that GC genotype for Resistin-420 C/G polymorphism is protective for ACS in obese patients in the Turkish population.

PPAR is a member of the nuclear hormone receptor family. There are three subtypes of PPAR: $\alpha, \delta$, and $\gamma(48)$. The PPAR- $\gamma$ plays a pivotal role on local vasculature in several critical aspects of atherothrombosis, including lipid metabolism and foam cell responses (49). A point mutation found on the $B$ exon of the $\mathrm{NH} 2$-terminal of PPAR- $\gamma$, substitution of proline with alanine at position 12, the Pro12Ala polymorphism, which causes an amino-acid substitution in its ligand-independent activation domain, and a moderate decrease in its transcriptional activity $(50,51)$. PPAR- $\gamma$ expression has also been found in atherosclerotic lesions and macrophages, suggesting that PPAR- $\gamma$ may influence atherogenic processes, and polymorphisms of PPAR- $\gamma$ may modulate individual susceptibility to T2DM, insulin resistance, obesity, and related traits associated with coronary heart disease $(48,49,52)$. Dedoussis et al. (53) reported that carrying the Ala allele for PPAR- $\gamma$ Pro12Ala polymorphism is a risk factor for adiposity in children. Pro12Ala and/or Ala12Ala polymorphisms of the PPAR- $\gamma$ gene have been found to be associated with obesity (54-57). The Ala/Ala genotype of the PPAR- $\gamma$ gene was found to be associated with obesity and insulin resistance in Asian Indians (58). In a meta-analysis, it was notified that the PPAR- $\gamma$ Pro12Ala polymorphism might be a risk factor for obesity susceptibility (59). On the contrary, some studies showed that the PPAR- $\gamma$ Pro12Ala polymorphism is not associated with obesity in different populations $(60,61)$. The relationship between the PPAR- $\gamma$ Pro12Ala polymorphism and coronary diseases were investigated in previous studies. No association has been found between PPAR- $\gamma$ Pro12Ala with ACS and coronary artery disease (62-64). In meta-analysis studies, the PPAR- $\gamma$ Pro12Ala polymorphism was not associated with coronary heart disease $(49,65)$. Wang et al. $(66)$ reported that although the 12Ala is not an independent risk factor for obesity, the PPAR- $\gamma$ Pro12Ala polymorphism is associated with increased risk of myocardial infarction in Han Chinese in Hohhot. In one study, the 12Ala allele in PPAR- $\gamma$ correlated with a significantly increased coronary artery disease extent in men (67), whereas in another study, it was reported that this allele had a protective effect for cardiovascular disease (68). No association was found with coronary artery disease and PPAR- $\gamma$ Pro12Ala polymorphism in Italian and Korean population $(69,70)$, whereas in the Turkish population, it was reported that carrying the 12Ala allele increased the risk of coronary artery disease (71). In the represented study, we found that the PPAR- $\gamma$ Pro12Ala polymorphism Pro/Ala genotype was found to be higher in the obese patients with ACS, while the Pro/Pro genotype was significantly higher in the control group. According to our results, it can be concluded that PPAR- $\gamma$ Pro12Ala polymorphism Pro/Ala genotype may be a risk factor for ACS in obesity patients, while the Pro/Pro genotype may be a protective factor for ACS in obesity.

Finally, regarding the results of this study, and showing compliance with the previous ones, PPAR- $\gamma$ Pro12Ala gene polymorphism may play a role in the development of ACS in obesity. Our results need to be confirmed in larger cohorts in order to improve the understanding of their role in the development of ACS in obesity patients.

\section{Study Limitation}

We believe that the small sample size in our study affected our results, and further studies with larger sample groups are needed to specifically clarify the role of the Leptin Gln223Arg, Resistin-420 C/G, and PPAR- $\gamma$ Pro12Ala gene polymorphisms in the pathogenesis of ACS in obese patients. However, even with 
the limited number of participants included in our study, we think that our findings will contribute to the understanding of the molecular mechanisms of ACS in obesity.

\section{CONCLUSION}

To date, no study had simultaneously evaluated the Leptin Gln223Arg, Resistin-420 C/G, and PPAR- $\gamma$ Pro12Ala polymorphisms in obese patients with ACS. Thus, our study is the first to focus on the above-mentioned polymorphisms in obese patients with ACS and we believe that it might be a relevant source of data for the further studies.

Ethics Committee Approval: This research complies with all the relevant national regulations, institutional policies and is in accordance the tenets of the Helsinki Declaration, and has been approved by the İstanbul Medical Faculty Ethical Committee, İstanbul University (approval number: 2012/1590-1251).

Informed Consent: All the participants' rights were protected and written informed consents were obtained before the procedures according to the Helsinki Declaration.

Peer-review: Externally peer-reviewed

Author Contributions: Concept - A.A., Ü.Z.; Design - Ü.Z., O.F., C.B.; Supervision - Ü.Y., N.Y.; Resources - O.F., C.B., F.Ç., A.A.; Materials - O.F., C.B., A.A.; Data Collection and/or Processing - A.A., F.Ç.; Analysis and/ or Interpretation - Ü.Z., A.A., Ü.Y., N.Y.; Literature Search - Ü.Z., A.A., F.Ç.; Writing Manuscript - Ü.Y., N.Y.; Critical Review - Ü.Z., Ü.Y., N.Y.

Conflict of Interest: The authors have no conflict of interest to declare.

Financial Disclosure: The authors declared that this study has received no financial support.

\section{REFERENCES}

1. Body R. Acute coronary syndromes diagnosis, version 2.0: Tomorrow's approach to diagnosing acute coronary syndromes? Turk J Emerg Med 2018; 18: 94-9.

2. Chan RSM, Woo J. Prevention of overweight and obesity: how effective is the current public health approach. Int J Environ Res Public Health 2010; 7: 765-83.

3. Budai KA, Mirzahosseini A, Béla N, Tóth G. [The pharmacotherapy of obesity]. Acta Pharm Hung 2015; 85: 3-17.

4. Abdelaal M, le Roux CW, Docherty NG. Morbidity and mortality associated with obesity. Ann Transl Med 2017; 5: 161.

5. Jiménez-Osorio AS, Musalem-Younes $C$, Cárdenas-Hernández $H$, Solares-Tlapechco J, Costa-Urrutia P, Medina-Contreras O, et al. Common Polymorphisms Linked to Obesity and Cardiovascular Disease in Europeans and Asians are Associated with Type 2 Diabetes in Mexican Mestizos. Medicina 2019; 55: 40.

6. Rankinen T, Sarzynski MA, Ghosh S, Bouchard C. Are there genetic paths common to obesity, cardiovascular disease outcomes, and cardiovascular risk factors? Circ Res 2015; 116: 909-22.

7. Hussain Z, Khan JA. Food intake regulation by leptin: Mechanisms mediating gluconeogenesis and energy expenditure. Asian Pac J Trop Med 2017; 10: 940-4.

8. Wu L, Sun D. Leptin receptor gene polymorphism and the risk of cardiovascular disease: A systemic review and meta-analysis. Int J Environ Res Public Health 2017; 14: 375.

9. de Oliveira R, Cerda A, Genvigir FDV, Sampaio MF, Armaganijan D, Bernik MM, et al. Leptin receptor gene polymorphisms are associated with adiposity and metabolic alterations in Brazilian individuals. Arq Bras Endocrinol Metabol 2013; 57:677-84.

10. Hashemi M, Bahari G, Tabasi F, Moazeni-Roodi A, Ghavami S. Association between rs 1862513 and rs3745367 genetic polymorphisms of resistin and risk of cancer: A meta-analysis. Asian Pac J Cancer Prev 2018; 19: 2709-16.
11. Tang NP, Wang LS, Yang L, Zhou B, Gu HJ, Sun QM, et al. A polymorphism in the resistin gene promoter and the risk of coronary artery disease in a Chinese population. Clin Endocrinol (Oxf) 2008; 68: 82-7.

12. Motawi TMK, Shaker OG, El-Sawalhi MM, Abdel-Nasser ZM. Visfatin $-948 \mathrm{G} / \mathrm{T}$ and resistin -420C/G polymorphisms in Egyptian type 2 diabetic patients with and without cardiovascular diseases. Genome 2014; 57 : 259-66.

13. Zayani N, Hamdouni H, Boumaiza I, Achour O, Neffati F, Omezzine A, et al. Resistin polymorphims, plasma resistin levels and obesity in Tunisian volunteers. J Clin Lab Anal 2018; 32: e 22227.

14. Hernandez-Romero D, Orenes-Pinero E, Garcia-Honrubia A, Climent V, Romero-Aniorte Al, Martinez CM, et al. Involvement of the $-420 \mathrm{C}>\mathrm{G}$ RETN polymorphism in myocardial fibrosis in patients with hypertrophic cardiomyopathy. J Intern Med 2015; 278: 50-8.

15. Corrales P, Izquierdo-Lahuerta A, Medina-Gómez G. Maintenance of kidney metabolic homeostasis by PPAR gamma. Int J Mol Sci 2018; 19: 2063.

16. Miller SA, Dykes DD, Polesky HF. A simple salting out procedure for extracting DNA from human nucleated cells. Nucleic Acids Res 1988; 16: 1215.

17. Ragin CC, Dallal C, Okobia M, Modugno F, Chen J, Garte S, et al. Leptin levels and leptin receptor polymorphism frequency in healthy populations. Infect Agent Cancer 2009; 4(Suppl 1): S13.

18. Guízar-Mendoza JM, Amador-Licona N, Flores-Martínez SE, LópezCardona MG, Ahuatzin-Trémary R, Sanchez-Corona J. Association analysis of the Gln223Arg polymorphism in the human leptin receptor gene, and traits related to obesity in Mexican adolescents. J Hum Hypertens 2005; 19: 341-6.

19. Bienertová-Vasků JA, Spinarová L, Bienert P, Vasků A. Association between variants in the genes for leptin, leptin receptor, and proopiomelanocortin with chronic heart failure in the Czech population. Heart Vessels 2009; 24: 131-7.

20. Shi R, Zhang M, Wang W, Song X, Liu H, Tian R, et al. Effect of interactions between LEPR polymorphisms and smoking on coronary artery disease susceptibility. Int J Clin Exp Pathol 2017; 10: 9753-9.

21. van der Vleuten GM, Kluijtmans LA, Hijmans A, Blom HJ, Stalenhoef $A F$, de Graaf J. The Gln223Arg polymorphism in the leptin receptor is associated with familial combined hyperlipidemia. Int J Obes (Lond) 2006; 30: 892-8.

22. Gotoda T, Manning BS, Goldstone AP, Imrie H, Evans AL, Strosberg AD, et al. Leptin receptor gene variation and obesity: lack of association in a white British male population. Hum Mol Genet 1997; 6: 869-76.

23. Silver K, Walston J, Chung WK, Yao F, Parikh VV, Andersen R, et al. The GIn223Arg and Lys656Asn polymorphisms in the human leptin receptor do not associate with traits related to obesity. Diabetes 1997; 46: 18981900.

24. Shabana NA, Hasnain S. Association of the leptin receptor Gln223 Arg polymorphism with lipid profile in obese Pakistani subjects. Nutrition 2015; 31: 1136-40.

25. Marginean CO, Marginean C, Voidazan S, Melit L, Crauciuc A, Duicu $C$, et al. Correlations between leptin gene polymorphisms $223 \mathrm{~A} / \mathrm{G}$, 1019 G/A, 492 G/C, 976 C/A, and Anthropometrical and Biochemical Parameters in Children With Obesity: A Prospective Case-Control Study in a Romanian Population-The Nutrichild Study. Medicine (Baltimore) 2016; 95: e3115.

26. Hassan NE, El-Masry SA, Zarouk W, El Banna RA, Mosaad RM, AlTohamy $M$, et al. Obesity phenotype in relation to gene polymorphism among samples of Egyptian children and their mothers. Genes Dis 2018; 5: 150-7.

27. Pyrzak B, Wisniewska A, Kucharska A, Wasik M, Demkow U. No association of LEPR GIn223Arg polymorphism with leptin, obesity or metabolic disturbances in children. Eur J Med Res 2009; 14(Suppl 4): 201 4.

28. Okada T, Ohzeki T, Nakagawa Y, Sugihara S, Arisaka O; Study Group of Pediatric O. Impact of leptin and leptin-receptor gene polymorphisms on serum lipids in Japanese obese children. Acta Paediatr 2010; 99: 12137.

29. Komşu-Ornek Z, Demirel F, Dursun A, Ermiş B, Pişkin E, Bideci A. Leptin receptor gene GIn223Arg polymorphism is not associated with obesity and metabolic syndrome in Turkish children. Turk J Pediatr 2012; 54: $20-$ 4. 
30. Yang GP, Peng SH, Zuo SY, Wang YR, Peng XN, Zeng XM. [Meta-analysis on the relationship between leptin receptor Gln223Arg and Pro1019Pro gene polymorphism and obesity in the Chinese population]. Zhonghua Liu Xing Bing Xue Za Zhi 2011; 32: 1037-42.

31. Masuo K, Straznicky NE, Lambert GW, Katsuya T, Sugimoto K, Rakugi H, et al. Leptin-receptor polymorphisms relate to obesity through blunted leptin-mediated sympathetic nerve activation in a Caucasian male population. Hypertens Res 2008; 31: 1093-100.

32. Khaki-Khatibi F, Mansouri F, Hajahmadipoorrafsanjani M, Ghojazadeh M, Gholikhani-Darbroud R. Study of rs1137101 polymorphism of leptin receptor gene with serum levels of selenium and copper in the patients of non-ST-segment elevation myocardial infarction (NSTEMI) in an Iranian population. Clin Biochem 2018; 60: 64-70.

33. Nowzari Z, Masoumi M, Nazari-Robati M, Akbari H, Shahrokhi N, Asadikaram G. Association of polymorphisms of leptin, leptin receptor and apelin receptor genes with susceptibility to coronary artery disease and hypertension. Life Sci 2018; 207: 166-71.

34. Aijälä $M$, Santaniemi $M$, Bloigu $R$, Kesäniemi $Y A$, Ukkola O. Leptin receptor Arg109 homozygotes display decreased total mortality as well as lower incidence of cardiovascular disease and related death. Gene 2014; 534: 88-92.

35. Rode PA, Kolte RA, Kolte AP, Purohit HJ, Ahuja CR. Relevance of singlenucleotide polymorphism to the expression of resistin gene affecting serum and gingival crevicular fluid resistin levels in chronic periodontitis and type 2 diabetes mellitus: A randomized control clinical trial. J Indian Soc Periodontol 2019; 23: 131-6.

36. Fu Y, Yu Y, Wu Y, You Y, Zhang Y, Kou C. Association between two resistin gene polymorphisms and metabolic syndrome in Jilin, Northeast China: A case-control study. Dis Markers 2017; 2017: 1638769.

37. Bouziana S, Tziomalos K, Goulas A, Vyzantiadis TA, Papadopoulou M, Panderi $A$, et al. Effects of major adipokines and the $-420 \mathrm{C}>\mathrm{G}$ resistin gene polymorphism on the long-term outcome of patients with acute ischemic stroke. Int J Neurosci 2019; 129: 978-85.

38. Hussain S, Haroon J, Ejaz S, Javed Q. Variants of resistin gene and the risk of idiopathic dilated cardiomyopathy in Pakistan. Meta Gene 2016; 9: 37-41.

39. Liu R, He B, Gao F, Liu Q, Yi Q. Association of the resistin gene promoter region polymorphism with Kawasaki disease in Chinese children. Mediators Inflamm 2012; 2012: 356362.

40. Zhu ZL, Yang OM, Li C, Chen J, Xiang M, Chen MM, et al. Association between the resistin gene- $420 \mathrm{C}>\mathrm{G}$ polymorphism and obesity: an updated meta-analysis. Eur Rev Med Pharmacol Sci 2016; 20: 4922-9.

41. El-Shal AS, Pasha HF, Rashad NM. Association of resistin gene polymorphisms with insulin resistance in Egyptian obese patients. Gene 2013; 515: 233-8.

42. Nakashima E, Watarai A, Tsukahara T, Hamada Y, Naruse K, Kamiya H, et al. Association of resistin polymorphism, its serum levels and prevalence of stroke in Japanese type 2 diabetic patients. J Diabetes Investig 2010; 1: 154-8.

43. Hoffmann MM, Pilz S, Weihrauch G, Seelhorst U, Wellnitz B, Winkelmann $B R$, et al. Effect of the resistin $-420 \mathrm{C}>\mathrm{G}$ polymorphism on cardiovascular disease and mortality. Clin Endocrinol (Oxf) 2008; 69: 344-5.

44. Hussain $\mathrm{S}$, Asghar $\mathrm{M}$, Javed $\mathrm{Q}$. Resistin gene promoter region polymorphism and the risk of hypertrophic cardiomyopathy in patients. Transl Res 2010; 155: 142-7.

45. Chi $S$, Lan $C$, Zhang $S$, Liu H, Wang $X$, Chen $Y$, et al. Association of $-394 \mathrm{C}>\mathrm{G}$ and $-420 \mathrm{C}>\mathrm{G}$ polymorphisms in the RETN gene with T2DM and CHD and a new potential SNP might be exist in exon 3 of RETN gene in Chinese. Mol Cell Biochem 2009; 330: 31-8.

46. Norata GD, Ongari M, Garlaschelli K, Tibolla G, Grigore L, Raselli S, et al. Effect of the $-420 \mathrm{C} / \mathrm{G}$ variant of the resistin gene promoter on metabolic syndrome, obesity, myocardial infarction and kidney dysfunction. J Intern Med 2007; 262: 104-12.

47. Qasim AN, Metkus TS, Tadesse M, Lehrke M, Restine S, Wolfe ML, et al. Resistin gene variation is associated with systemic inflammation but not plasma adipokine levels, metabolic syndrome or coronary atherosclerosis in nondiabetic Caucasians. Clin Endocrinol (Oxf) 2009; 70: 698-705

48. Rhee EJ, Oh KW, Lee WY, Kim SY, Oh ES, Baek KH, et al. Effects of two common polymorphisms of peroxisome proliferator-activated receptorgamma gene on metabolic syndrome. Arch Med Res 2006; 37: 86-94.
49. Xu W, Xu J, Sun B, Chen H, Wang Y, Huang F, et al. The effect of PPARG gene polymorphisms on the risk of coronary heart disease: a metaanalysis. Mol Biol Rep 2013; 40: 875-84.

50. Horiki M, Ikegami H, Fujisawa $T$, Kawabata $Y$, Ono $M$, Nishino $M$, et al. Association of Pro12Ala polymorphism of PPARgamma gene with insulin resistance and related diseases. Diabetes Res Clin Pract 2004; 66 Suppl 1: S63-7.

51. Mansoori A, Amini M, Kolahdooz F, Seyedrezazadeh E. Obesity and Pro12Ala polymorphism of peroxisome proliferator-activated receptorgamma gene in healthy adults: A systematic review and meta-analysis. Ann Nutr Metab 2015; 67: 104-18.

52. Wojtkowska I, Bonda TA, Tysarowski A, Seliga K, Siedlecki JA, Winnicka MM, Stępińska J. PPARG2 Pro12Ala and TNFalpha -308G>A polymorphisms are not associated with heart failure development in patients with ischemic heart disease after coronary artery bypass grafting. PPAR Res 2019; 2019: 1932036.

53. Dedoussis GV, Vidra N, Butler J, Papoutsakis C, Yannakoulia M, Hirschhorn JN, et al. Peroxisome proliferator-activated receptor-gamma (PPARgamma) Pro12Ala polymorphism and risk for pediatric obesity. Clin Chem Lab Med 2009; 47: 1047-50.

54. Ben Ali S, Ben Yahia F, Sediri Y, Kallel A, Ftouhi B, Feki M, et al. Genderspecific effect of Pro12Ala polymorphism in peroxisome proliferatoractivated receptor gamma-2 gene on obesity risk and leptin levels in a Tunisian population. Clin Biochem 2009; 42: 1642-7.

55. Bidzińska B, Demissie M, Tworowska U, Slezak R, Dobosz T, Milewicz A. [ls obesity associated with a polymorphism Pro12Ala and Pro115Gln in the PPARgamma gene?]. Pol Merkur Lekarski 2004; 17: 361-4.

56. Mattevi VS, Zembrzuski VM, Hutz MH. Effects of a PPARG gene variant on obesity characteristics in Brazil. Braz J Med Biol Res 2007; 40: 927-32.

57. Prakash J, Srivastava N, Awasthi S, Agarwal C, Natu S, Rajpal N, et al. Association of PPAR- $\gamma$ gene polymorphisms with obesity and obesityassociated phenotypes in North Indian population. Am J Hum Biol 2012; 24: 454-9.

58. Bhatt SP, Misra A, Sharma M, Luthra K, Guleria R, Pandey RM, et al. Ala/Ala genotype of Pro12Ala polymorphism in the peroxisome proliferator-activated receptor-gamma2 gene is associated with obesity and insulin resistance in Asian Indians. Diabetes Technol Ther 2012; 14: 828-34.

59. Yao YS, Li J, Jin YL, Chen Y, He LP. Association between PPAR- $\gamma 2$ Pro12Ala polymorphism and obesity: a meta-analysis. Mol Biol Rep 2015; 42: 102938.

60. Kuliczkowska J, Filus A, Trzmiel A, Tworowska U, Demissie M, Jedrzejuk $D$, et al. PPAR-gamma2 Pro12Ala polymorphism in the population of obese and non-obese men of the city of Wroclaw. Endokrynol Pol 2008; 59: 312-5.

61. Ghoussaini M, Meyre D, Lobbens S, Charpentier G, Clément K, Charles $M A$, et al. Implication of the Pro12Ala polymorphism of the PPAR-gamma 2 gene in type 2 diabetes and obesity in the French population. BMC Med Genet 2005; 6: 11.

62. Evangelisti L, Attanasio M, Lucarini L, Sofi F, Marcucci R, Giglioli C, et al. PPARgamma promoter polymorphisms and acute coronary syndrome. Atherosclerosis 2009; 205: 186-91.

63. Vogel U, Segel S, Dethlefsen C, Tjønneland A, Saber AT, Wallin H, et al. PPARgamma Pro12Ala polymorphism and risk of acute coronary syndrome in a prospective study of Danes. BMC Med Genet 2009; 10: 52.

64. Rhee EJ, Kwon CH, Lee WY, Kim SY, Jung CH, Kim BJ, et al. No association of Pro12Ala polymorphism of PPAR-gamma gene with coronary artery disease in Korean subjects. Circ J 2007; 71: 338-42.

65. Ding S, Liu L, Zhuge QC, Yu Z, Zhang X, Xie J, et al. The meta-analysis of the association of PPARG P12A, C161T polymorphism and coronary heart disease. Wien Klin Wochenschr 2012; 124: 671-7.

66. Wang LP, Zhao LR, Cui HW, Yan MR, Yang L, Su XL. Association between PPARgamma2 Pro12Ala polymorphism and myocardial infarction and obesity in Han Chinese in Hohhot, China. Genet Mol Res 2012; 11: 292938.

67. Schneider JG, Schiekofer S, von Eynatten M, Schlimmer P, Dugi KA. The proline 12 alanine substitution in the PPARgamma2 gene is associated with increased extent of coronary artery disease in men. Exp Clin Endocrinol Diabetes 2009; 117: 519-21.

68. Regieli JJ, Jukema JW, Doevendans PA, Zwinderman AH, van der Graaf $Y$, Kastelein JJ, et al. PPAR gamma variant influences angiographic 
outcome and 10-year cardiovascular risk in male symptomatic coronary artery disease patients. Diabetes Care 2009; 32: 839-44.

69. Galgani A, Valdes A, Erlich HA, Mano C, Cheng S, Petrone A, et al. Homozygosity for the Ala allele of the PPARgamma2 Pro12Ala polymorphism is associated with reduced risk of coronary artery disease. Dis Markers 2010; 29: 259-64.

70. Rhee EJ, Kwon CH, Lee WY, Kim SY, Jung CH, Kim BJ, et al. No association of Pro12Ala polymorphism of PPAR-gamma gene with coronary artery disease in Korean subjects. Circ J 2007; 71: 338-42.
71. Aydoğan HY, KüçükhüseyinO, Tekeli $A$, Isbir T. Associations of receptor for advanced glycation end products -374 T/A and Gly82 Ser and peroxisome proliferator-activated receptor gamma Pro12Ala polymorphisms in Turkish coronary artery disease patients. Genet Test Mol Biomarkers 2012; 16: 134-7. 